\title{
Synthesis of triphenylamine-cored dendritic two-photon absorbing chromophores
}

Peng Wei, ${ }^{\dagger}$ Xiangdong $\mathrm{Bi}^{\mathrm{t}, \star}{ }^{\dagger} \mathrm{Zhe} \mathrm{Wu}^{\dagger}$ and $\mathrm{Zhi} \mathrm{Xu}^{\ddagger}$

Department of Chemistry, University of Missouri-Kansas City,

Kansas City, Missouri 64110, USA

Department of Chemistry and Biochemistry, University of Missouri-

St. Louis, St. Louis, Missouri 63121, USA

xiabi@umich.edu

\section{Experimental Section:}<smiles>O=C(c1ccccc1)n1cccc1-c1ccccc1</smiles>

$\boldsymbol{N}, \boldsymbol{N}$-diphenylbenzamide (2). Compound 2 was prepared based on a modification of a reported procedure. ${ }^{1}$ Diphenylamine $(5.076 \mathrm{~g}, 30 \mathrm{mmol})$ and pyridine $(10 \mathrm{~mL})$ were charged into a $50 \mathrm{~mL}$-round-bottom flask. Benzoyl chloride $(4.15 \mathrm{~mL}, 36 \mathrm{mmol})$ was added slowly with stirring at $0{ }^{\circ} \mathrm{C}$. The reaction mixture was warmed to room temperature and stirred overnight. The resulting mixture was poured into $500 \mathrm{~mL} 10 \% \mathrm{HCl}$ ice-water solution and extracted by chloroform. The chloroform solution was washed with $200 \mathrm{~mL}$ water, $5 \% \mathrm{HCl}$ solution and $5 \% \mathrm{NaOH}$ solution, successively. The solvent was evaporated to give the crude product, which was recrystallized from benzene to give off-white crystals $(7.051 \mathrm{~g}$, yield 86\%). ${ }^{1} \mathrm{H}$ NMR $\left(\mathrm{CDCl}_{3}, 250 \mathrm{MHz}\right) \delta$ 7.84-7.50 (m, $\left.15 \mathrm{H}\right) ;{ }^{13} \mathrm{C} \mathrm{NMR}\left(\mathrm{CDCl}_{3}, 62.9 \mathrm{MHz}\right)$ $\delta 170.82,144.03,136.23,130.33,129.32,128.04,127.65,126.53$.<smiles>O=C(c1ccccc1)N(c1ccc(Br)cc1)c1ccc(Br)cc1</smiles>

$N, N$-Bis-(4-bromophenyl)benzamide (3). Compound 3 was synthesized by following a reported procedure. ${ }^{2}$ A chloroform solution $(20 \mathrm{~mL})$ of compound $2(0.87 \mathrm{~g}, 3.2 \mathrm{mmol})$ was treated with bromine $(0.36 \mathrm{~mL}, 7.0 \mathrm{mmol})$. The mixture was stirred at $40{ }^{\circ} \mathrm{C}$ for 8 hours and monitored by TLC until all of compound 2 was consumed. The crude product was 
recrystallized from absolute ethanol to give the pure product $(1.310 \mathrm{~g}$, yield $95 \%) .{ }^{1} \mathrm{H}$ NMR $\left(\mathrm{CDCl}_{3}, 250 \mathrm{MHz}\right) \delta$ 7.46-7.23 (m, $\left.9 \mathrm{H}\right), 7.03(\mathrm{~d}, 4 \mathrm{H}) ;{ }^{13} \mathrm{C} \mathrm{NMR}\left(\mathrm{CDCl}_{3}, 62.9\right.$ MHz) $\delta 170.51,142.71,135.34,132.54,130.84,129.28,129.05,128.31,120.24$.

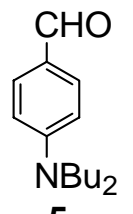

4- $N, N$-Dibutylaminobenzaldehyde (5). Compound 5 was synthesized by following a reported procedure. ${ }^{3}$ Phosphorous oxychloride $(1.86 \mathrm{~mL}, 20 \mathrm{mmol})$ was added dropwise to DMF $(7 \mathrm{~mL})$ at $0{ }^{\circ} \mathrm{C}$ under nitrogen. The mixture was stirred for 40 minutes and $N, N$-dibutylaniline $(4.53 \mathrm{~mL}, 20 \mathrm{mmol})$ was added dropwise at room temperature. The reaction mixture was stirred at room temperature for 15 minutes, then stirred at $110^{\circ} \mathrm{C}$ overnight. The reaction was monitored by TLC until no more starting material existed. The reaction mixture was poured into ice water and neutralized by $3 \mathrm{~N} \mathrm{NaOH}$ solution. The solution was extracted by ethyl acetate. The solvent was evaporated to give a brown oil, which was separated by column chromatography (silica gel, ethyl acetate:hexanes $=1: 10)$ to yield product $5(4.21 \mathrm{~g}$, yield $92 \%) .{ }^{1} \mathrm{H} \mathrm{NMR}\left(\mathrm{CDCl}_{3}\right.$, $250 \mathrm{MHz}) \delta 9.70(\mathrm{~s}, 1 \mathrm{H}), 7.71(\mathrm{~d}, \mathrm{~J}=10 \mathrm{~Hz}, 2 \mathrm{H}), 6.65(\mathrm{~d}, \mathrm{~J}=10 \mathrm{~Hz}, 2 \mathrm{H}), 3.35(\mathrm{t}, \mathrm{J}=$ $7.5 \mathrm{~Hz}, 4 \mathrm{H}), 1.60(\mathrm{~m}, 4 \mathrm{H}), 1.39(\mathrm{~m}, 4 \mathrm{H}), 0.98(\mathrm{t}, 6 \mathrm{H}) ;{ }^{13} \mathrm{C} \mathrm{NMR}\left(\mathrm{CDCl}_{3}, 62.9 \mathrm{MHz}\right) \delta$ $191.54,152.57,132.66,125.87,111.82,51.46,29.29,20.36,14.08$.

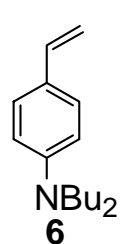

4-N,N-dibutylaminostyrene (6). Compound 6 was prepared based on a modification of a reported procedure. ${ }^{4}$ In a nitrogen-filled glovebox, methyltriphenyl phosphonium iodide (8.08 g, $20 \mathrm{mmol})$ and THF $(50 \mathrm{~mL})$ were added to a 250 -mL round bottom flask. The flask was taken out of the glovebox and was cooled to $-80{ }^{\circ} \mathrm{C}$ in a dry ice-acetone bath. A solution of BuLi (1.6 M solution in hexane, $12.5 \mathrm{~mL}$ ) was added via syringe under nitrogen. The reaction mixture was allowed to stir at $-80{ }^{\circ} \mathrm{C}$ for 1 hour and then warmed to room temperature for another 1- 
hour period. A solution of 4-N,N'-dibutylaminobenzaldehyde (4.66 g, $20 \mathrm{mmol})$ in 15 $\mathrm{mL}$ of THF was added dropwise. The reaction mixture was stirred at room temperature overnight. After reaction, most of the THF was evaporated and the solution was diluted with hexanes. Most of the salts was removed by filtration. The compound was purified using a basic alumina column yielding product 6 (4.56 g, yield 98\%). ${ }^{1} \mathrm{H} \mathrm{NMR}\left(\mathrm{CDCl}_{3}\right.$, $250 \mathrm{MHz}) \delta 7.33(\mathrm{~d}, \mathrm{~J}=10 \mathrm{~Hz}, 2 \mathrm{H}), 6.65(\mathrm{~d}, \mathrm{~J}=10 \mathrm{~Hz}, 2 \mathrm{H}), 5.57(\mathrm{~d}, \mathrm{~J}=20 \mathrm{~Hz}, 1 \mathrm{H})$, $5.03(\mathrm{~d}, \mathrm{~J}=10 \mathrm{~Hz}, 1 \mathrm{H}), 3.34(\mathrm{t}, \mathrm{J}=7.5 \mathrm{~Hz}, 4 \mathrm{H}), 1.63(\mathrm{~m}, 4 \mathrm{H}), 1.42(\mathrm{~m}, 4 \mathrm{H}), 1.01$ (t, 6 $\mathrm{H}) ;{ }^{13} \mathrm{C} \mathrm{NMR}\left(\mathrm{CDCl}_{3}, 62.9 \mathrm{MHz}\right) \delta 148.03,138,81,127.42,124.93,117.55,108.69$, $50.96,29.59,20.53,14.19$.

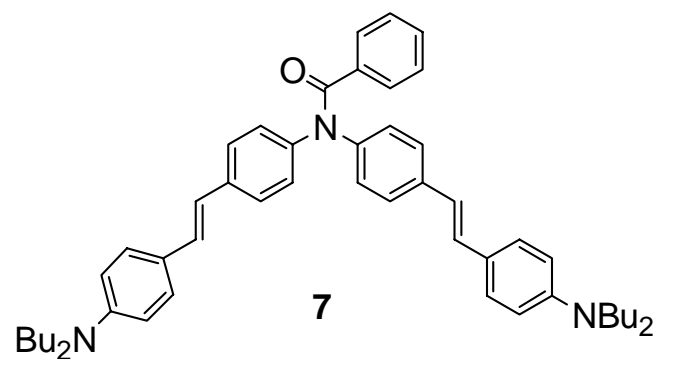

$N, N$-Bis- $\{4-[2-(4-$

\section{dibutylaminophenyl)vinyl]phenyl\}benzami}

de (7). To a Schlenk tube equipped with a Teflon valve was added $\mathbf{3}(0.431 \mathrm{~g}, 1 \mathrm{mmol})$, 4- $N, N$-dibutylaminostyrene $(0.557 \mathrm{~g}, 2.4 \mathrm{mmol}), \mathrm{Pd}(\mathrm{OAc})_{2}(15 \mathrm{mg}, 0.067 \mathrm{mmol})$, tri-otolylphosphine (40.2 mg, $0.134 \mathrm{mmol}), \mathrm{Et}_{3} \mathrm{~N}(2 \mathrm{~mL}, 14.3 \mathrm{mmol})$ and anhydrous DMF (4 $\mathrm{mL}$ ). Nitrogen was bubbled through the solution for 5 minutes. The tube was sealed and heated at $100{ }^{\circ} \mathrm{C}$ for 3 days. The reaction mixture was then poured into $200 \mathrm{~mL}$ water and extracted using $500 \mathrm{~mL}$ ethyl acetate. The crude product was purified by column chromatography (silica gel, hexane:ethyl acetate $=1: 10)$ to give pure product $7(0.621 \mathrm{~g}$, yield 85\%). ${ }^{1} \mathrm{H}$ NMR $\left(\mathrm{CDCl}_{3}, 250 \mathrm{MHz}\right) \delta$ 7.59-6.66 (m, $\left.25 \mathrm{H}\right), 3.35(\mathrm{t}, 8 \mathrm{H}), 1.65(\mathrm{~m}, 8$ $\mathrm{H}), 1.46(\mathrm{~m}, 8 \mathrm{H}), 1.05(\mathrm{t}, 12 \mathrm{H}) ;{ }^{13} \mathrm{C} \mathrm{NMR}\left(\mathrm{CDCl}_{3}, 62.9 \mathrm{MHz}\right) \delta 170.58,147.96,142.13$, $136.50,136.38,130.25,129.43,129.32,128.00,127.92,127.49,126.52,124.31,122.60$, 111.66, 50.83, 29.56, 20.44, 14.15 . 


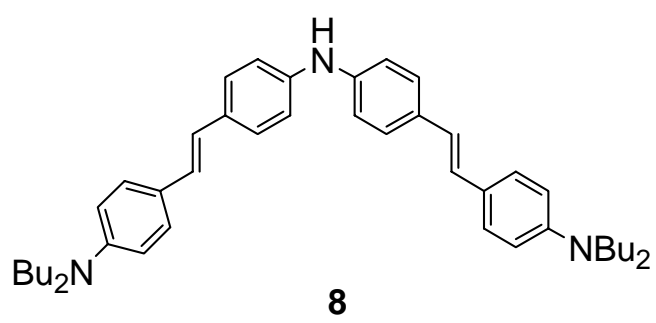

$(E, E)-b i s(4-(2-(4-N, N-$ dibutylaminophenyl)ethenyl)phenyl)amine

(8). Clasien's alkali was prepared by following a literature procedure. ${ }^{5}$ Potassium hydroxide

$(8.80 \mathrm{~g})$ was dissolved in $6.1 \mathrm{~mL}$ of water and diluted to $25 \mathrm{~mL}$ with methanol. Compound 7 (0.601 g, $0.82 \mathrm{mmol})$ was dissolved in $25 \mathrm{~mL}$ THF and Clasien's alkali (25 $\mathrm{mL}$ ) was added. The resulting solution was refluxed for 12 hours. The resulting mixture was poured into water and extracted with ethyl acetate. The solvent was evaporated to give product 8 as a bright yellow solid $(0.508 \mathrm{~g}$, yield $99 \%) .{ }^{1} \mathrm{H} \mathrm{NMR}\left(\mathrm{CDCl}_{3}, 250 \mathrm{MHz}\right)$ $\delta 7.51(\mathrm{~d}, 8 \mathrm{H}), 7.13(\mathrm{~d}, 4 \mathrm{H}), 7.04(\mathrm{~d}, 4 \mathrm{H}), 6.78(\mathrm{~d}, 4 \mathrm{H}), 5.32(\mathrm{~s}, 1 \mathrm{H}), 3.43(\mathrm{t}, 8 \mathrm{H}), 1.72$ $(\mathrm{m}, 8 \mathrm{H}), 1.51(\mathrm{~m}, 8 \mathrm{H}), 1.13(\mathrm{t}, 12 \mathrm{H}) ;{ }^{13} \mathrm{C} \mathrm{NMR}\left(\mathrm{CDCl}_{3}, 62.9 \mathrm{MHz}\right) \delta 147.57,141.63$ $131.26,127.58,127.07,126.61,125.09,123.62,117.91,111.86,50.87,29.60,20.48$, 14.19.

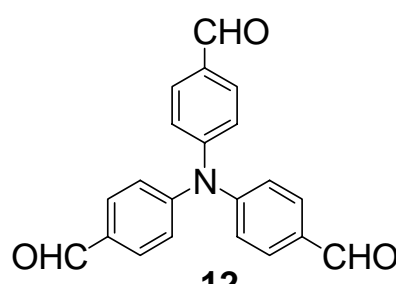

12
Tris(4-formylphenyl)amine (12). Compound 12 was synthesized by following a modification of a procedure reported by Lai. ${ }^{3}$ Triphenylamine $(4.900 \mathrm{~g}, 20 \mathrm{mmol})$ and anhydrous DMF $(40 \mathrm{~mL})$ were added to a $250-\mathrm{mL}$ round

bottom flask under nitrogen. The mixture was cooled to $0^{\circ} \mathrm{C}$ and phosphorus oxychloride (37.0 $\mathrm{mL}, 420 \mathrm{mmol}$ ) was added dropwise via syringe. The reaction mixture was heated at $95-100^{\circ} \mathrm{C}$ for 2 days. The resulting mixture was poured into ice water and neutralized with $3 \mathrm{~N} \mathrm{NaOH}$. The crude product was collected by filtration and purified by column chromatography ( silica gel, hexanes:ethyl acetate $=4: 1)$ to obtain pure product $(2.303 \mathrm{~g}$, 
yield 35\%). ${ }^{1} \mathrm{H}$ NMR $\left(\mathrm{CDCl}_{3}, 250 \mathrm{MHz}\right) \delta 9.96(\mathrm{~s}, 3 \mathrm{H}), 7.88(\mathrm{~d}, 6 \mathrm{H}), 7.30(\mathrm{~d}, 6 \mathrm{H}) ;{ }^{13} \mathrm{C}$ $\operatorname{NMR}\left(\mathrm{CDCl}_{3}, 62.9 \mathrm{MHz}\right) \delta 190.72,151.39,132.74,131.70,124.74$.

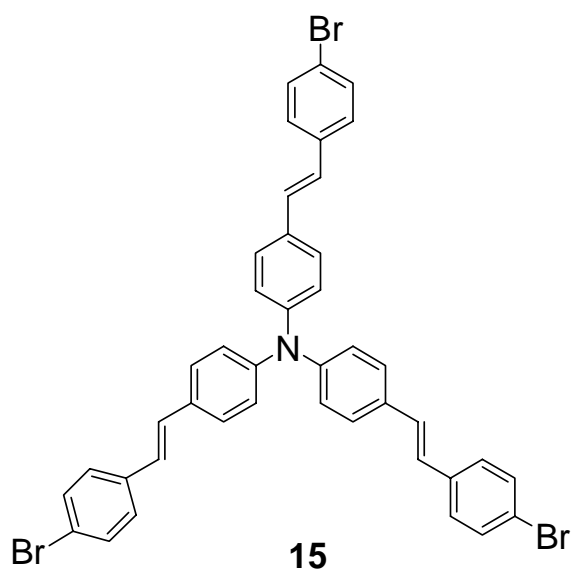

Compound 15: To a 50-mL round bottom flask equipped with a water condenser and a drying tube were added 4-bromobenzylbromide (4.998 g, 20 mmol) and triethyl phosphite $(20 \mathrm{~mL})$. The reaction mixture was heated to $160{ }^{\circ} \mathrm{C}$ for 2 hours. The excess triethyl phosphite was removed by vacuum. The resulting viscous phosphate $\mathbf{1 4}$ was used

without further purification. In a nitrogen-filled glovebox, sodium hydride $(760 \mathrm{mg}, 31.6$ mmol) and DMF ( $80 \mathrm{~mL}$ ) were added to a $250-\mathrm{mL}$ round bottom flask. The flask was taken out of the glovebox and a $20 \mathrm{~mL}$ solution of phosphate $\mathbf{1 4}$ in DMF was added via syringe. After stirring at room temperature for 1 hour, a solution of $\mathbf{1 2}(19.7 \mathrm{~g}, 60 \mathrm{mmol})$ in DMF (20 mL) was added dropwise via syringe. The resulting mixture was stirred at room temperature for 1 hour and then heated at $90^{\circ} \mathrm{C}$ for 4 days. After reaction, DMF was evaporated to form a black solid, which was re-dissolved in ethyl acetate and washed with water. The crude product was purified by column chromatography (silica gel, hexane:benzene $=1: 1)$ to give pure product $15(8.98 \mathrm{~g}, 39 \%)$ 


\section{${ }^{1} \mathrm{H}$ and ${ }^{13} \mathrm{C}$ NMR spectra of 9,10 , and 16 :}

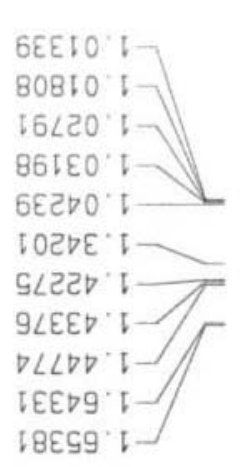

SEIGE ' $\varepsilon$ EดIgE' $\varepsilon$
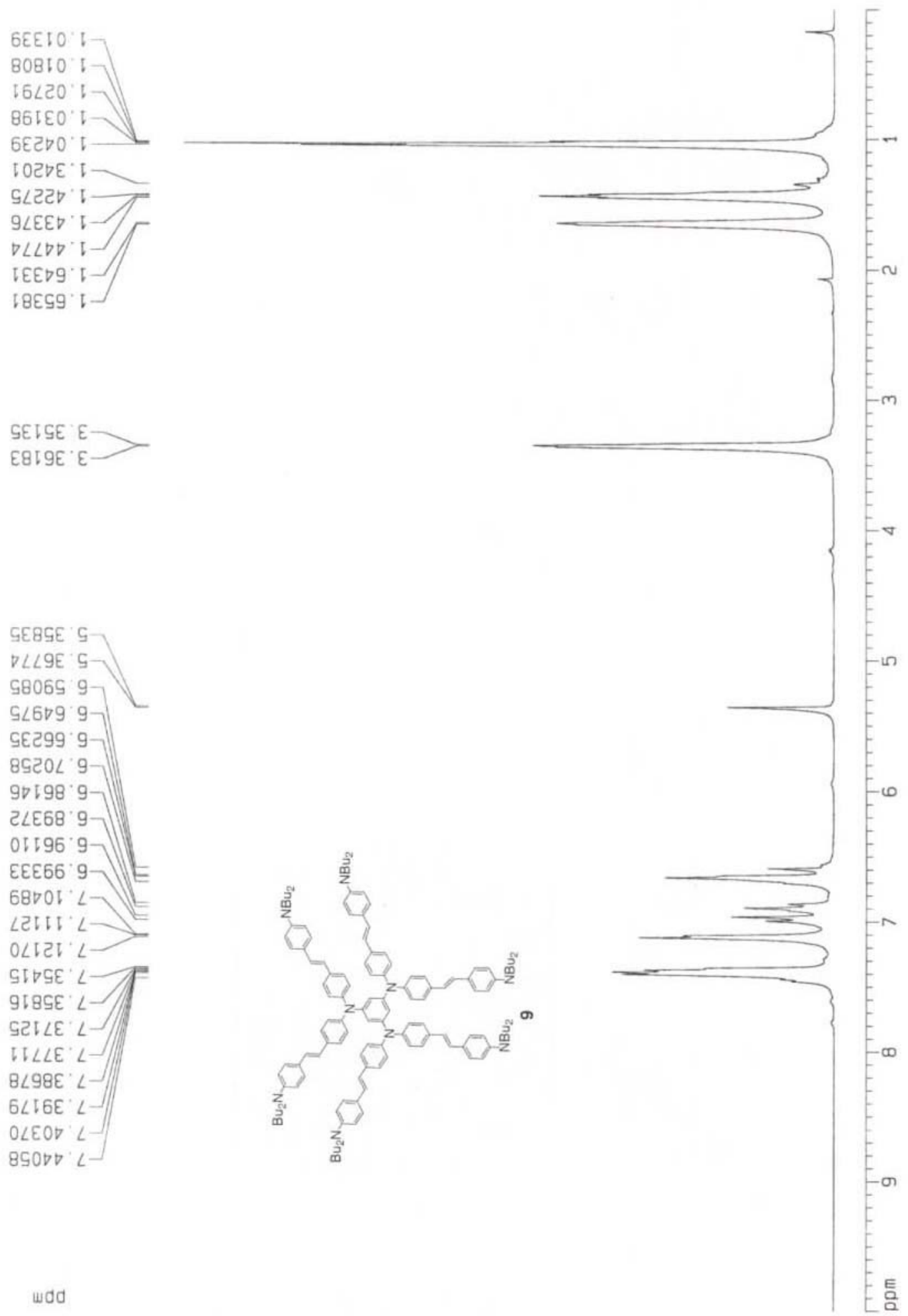


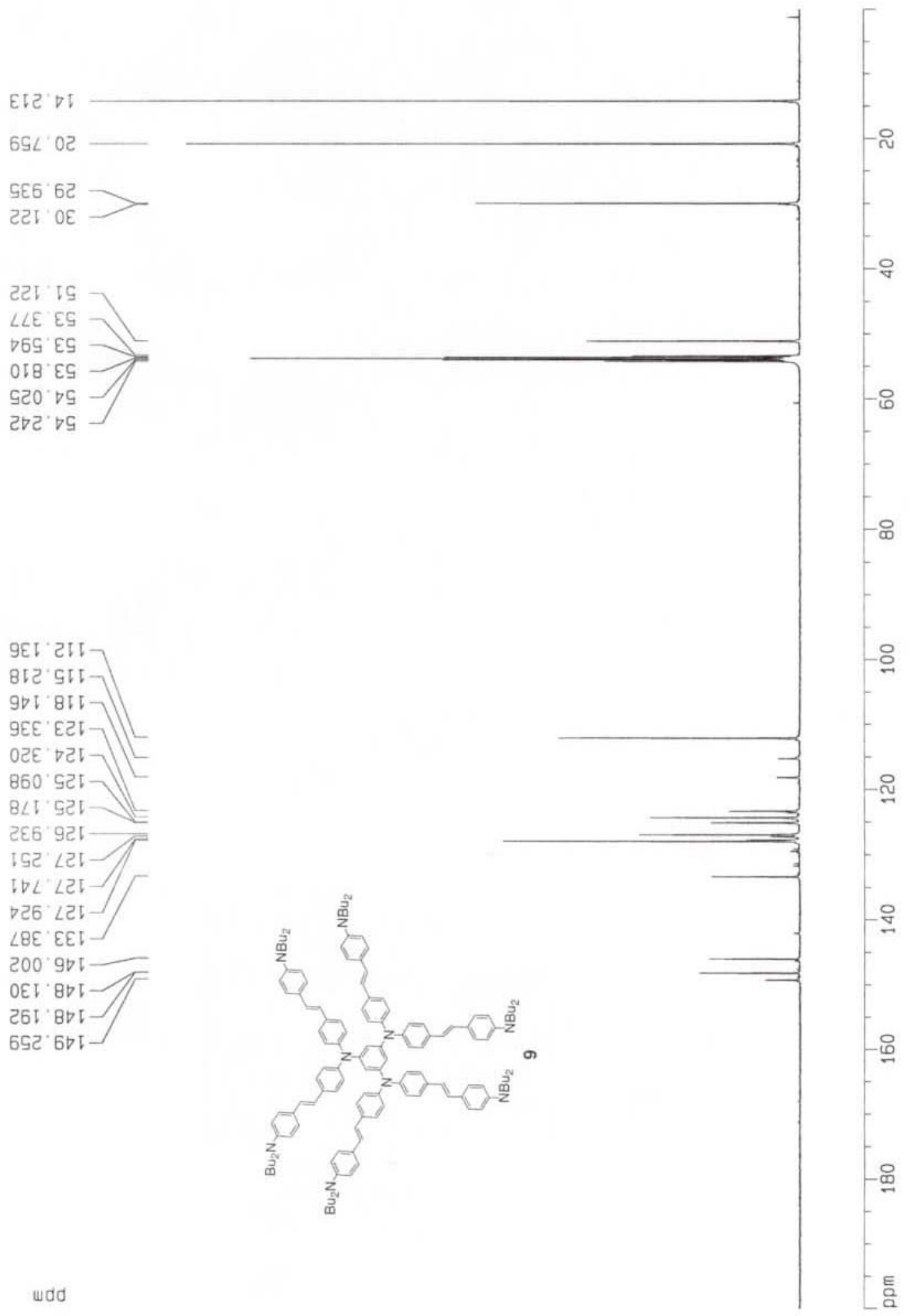




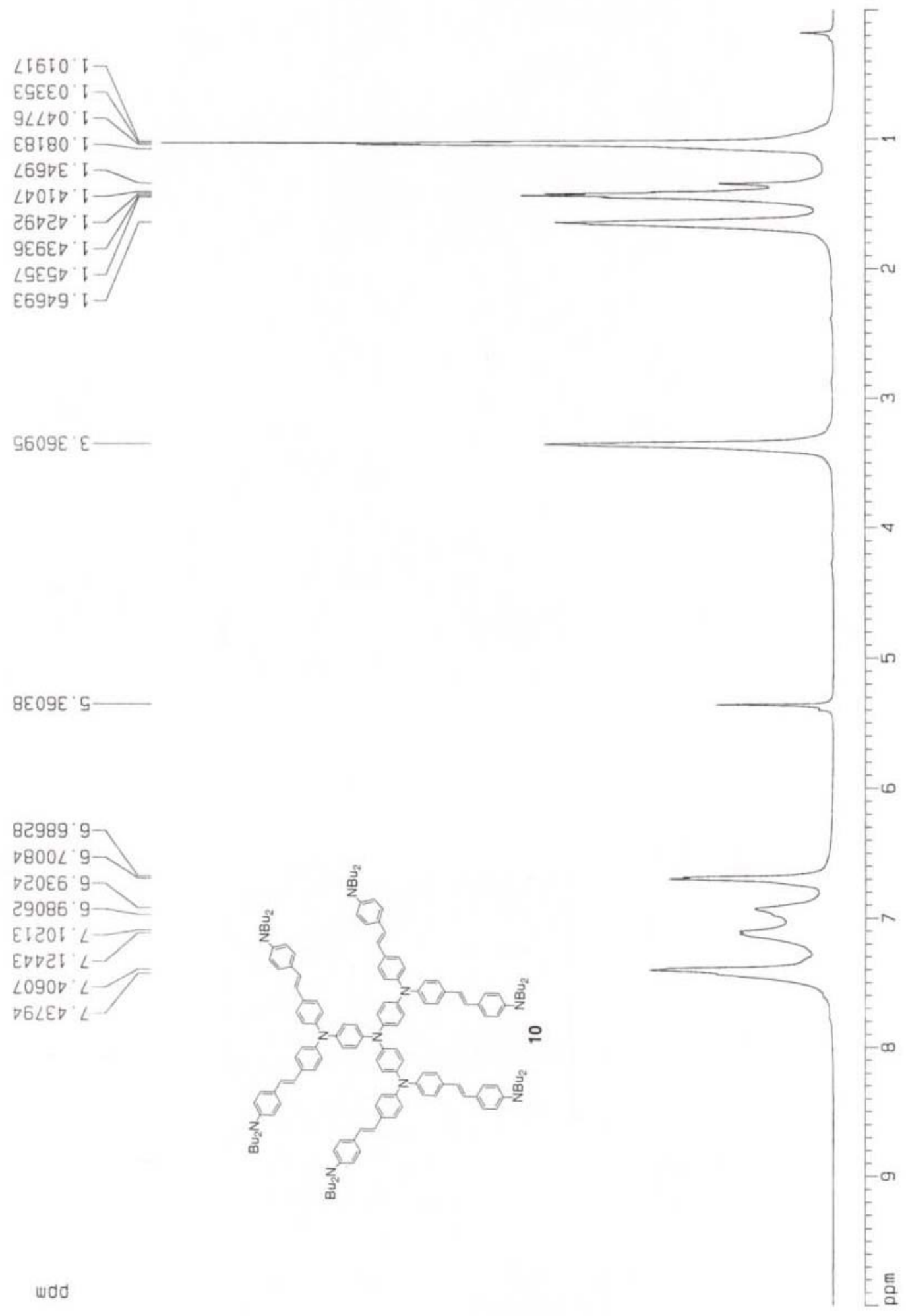




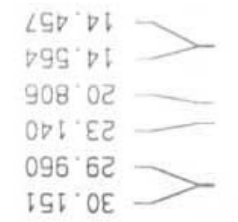

VLIIS

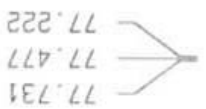

561 211

SDL EटL$161 \rightarrow 21-$ 68E $521-$ $\triangle 21 . \angle 5 I-T$ $\angle 98^{\circ} \angle 21$ $166^{\circ}[21]$

$D E O^{\circ} B D$

wdd

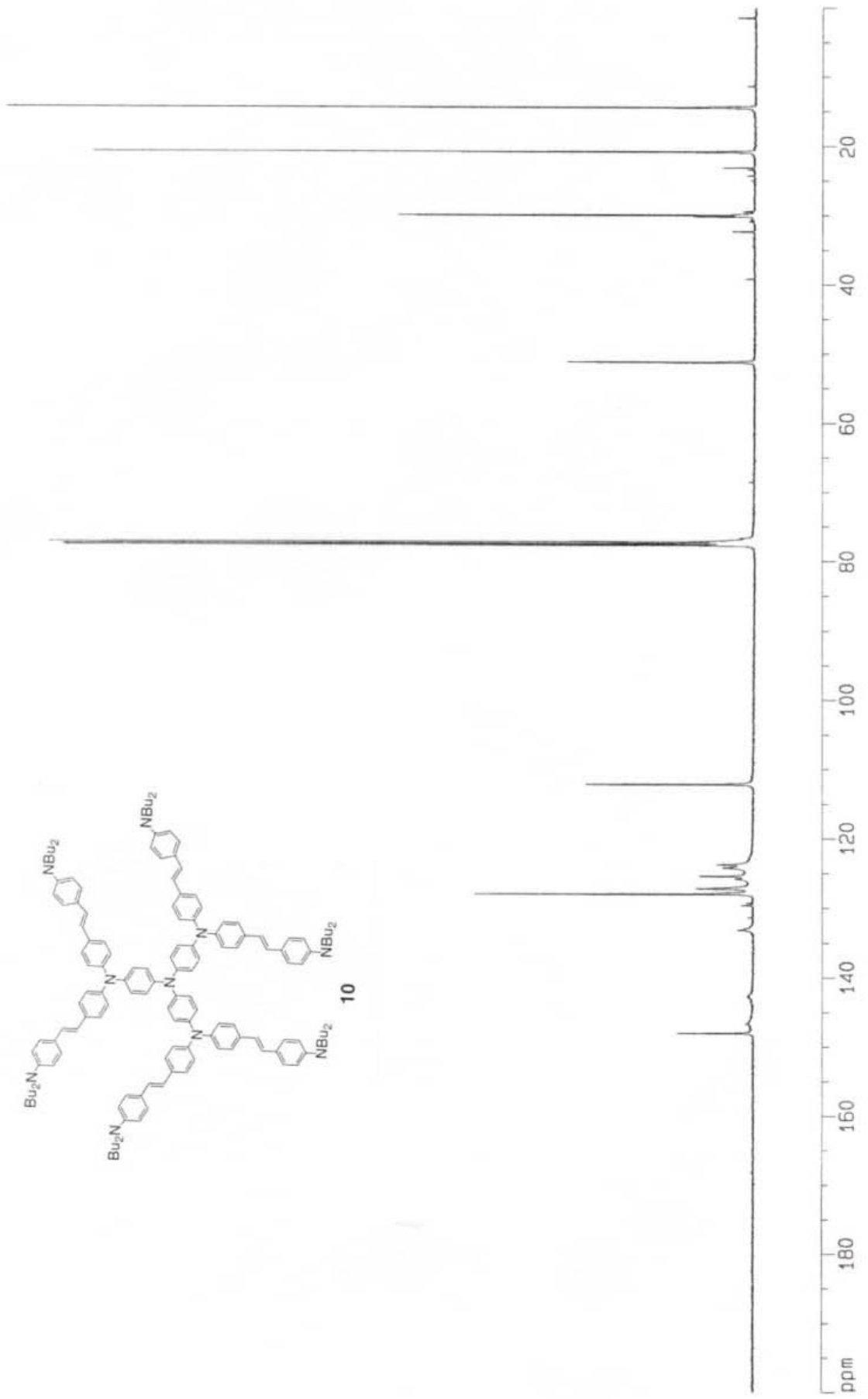




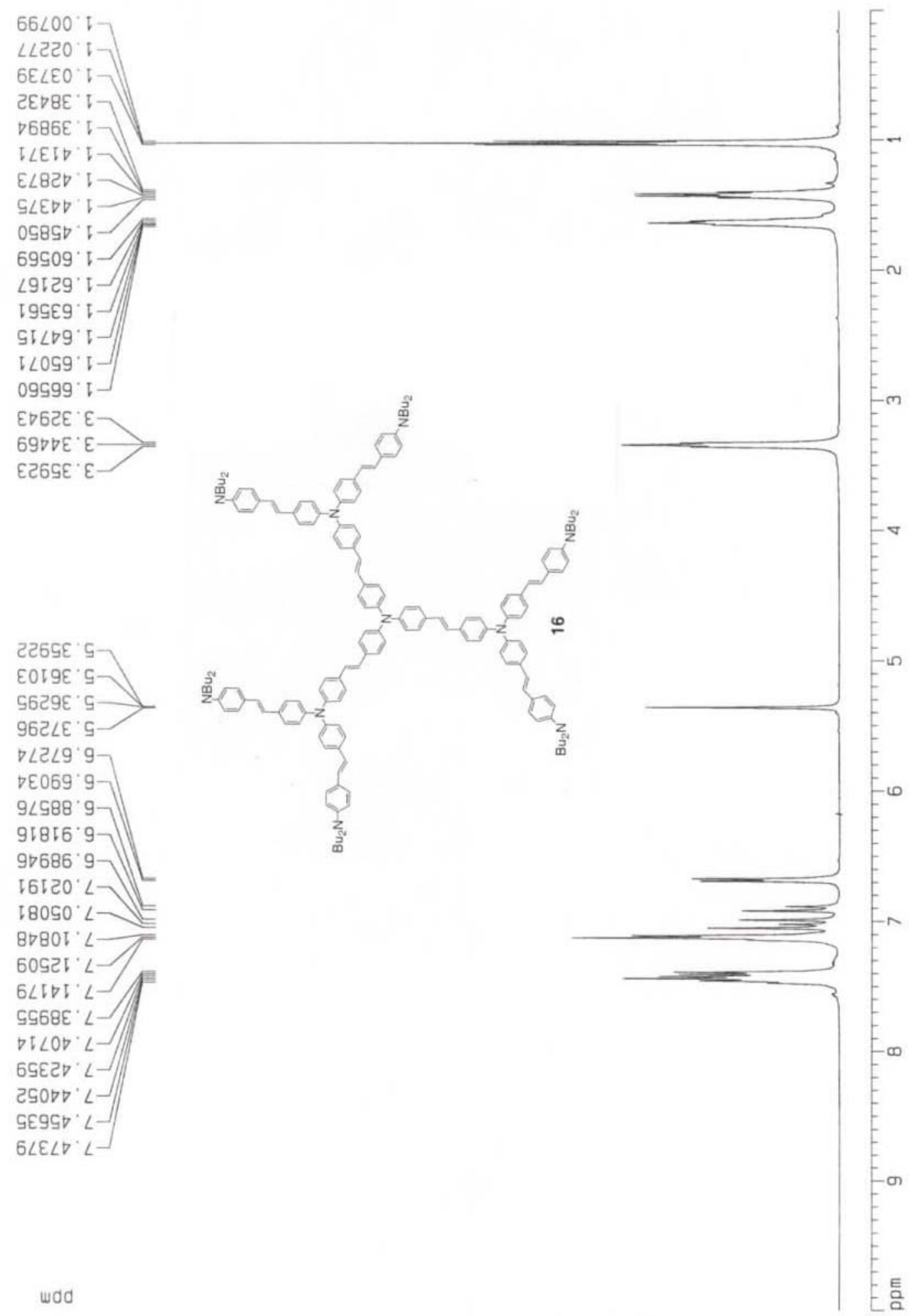


$68 T^{\circ} \circ 5$

EEL OZ

$268^{\circ} 62$

IIt IS ¿LE' $E S$ 88. ' $E G^{\circ}$ 与08 ' $E \subseteq$ Iट0 $\mathrm{CS}$ वहट $\square \mathrm{G}$

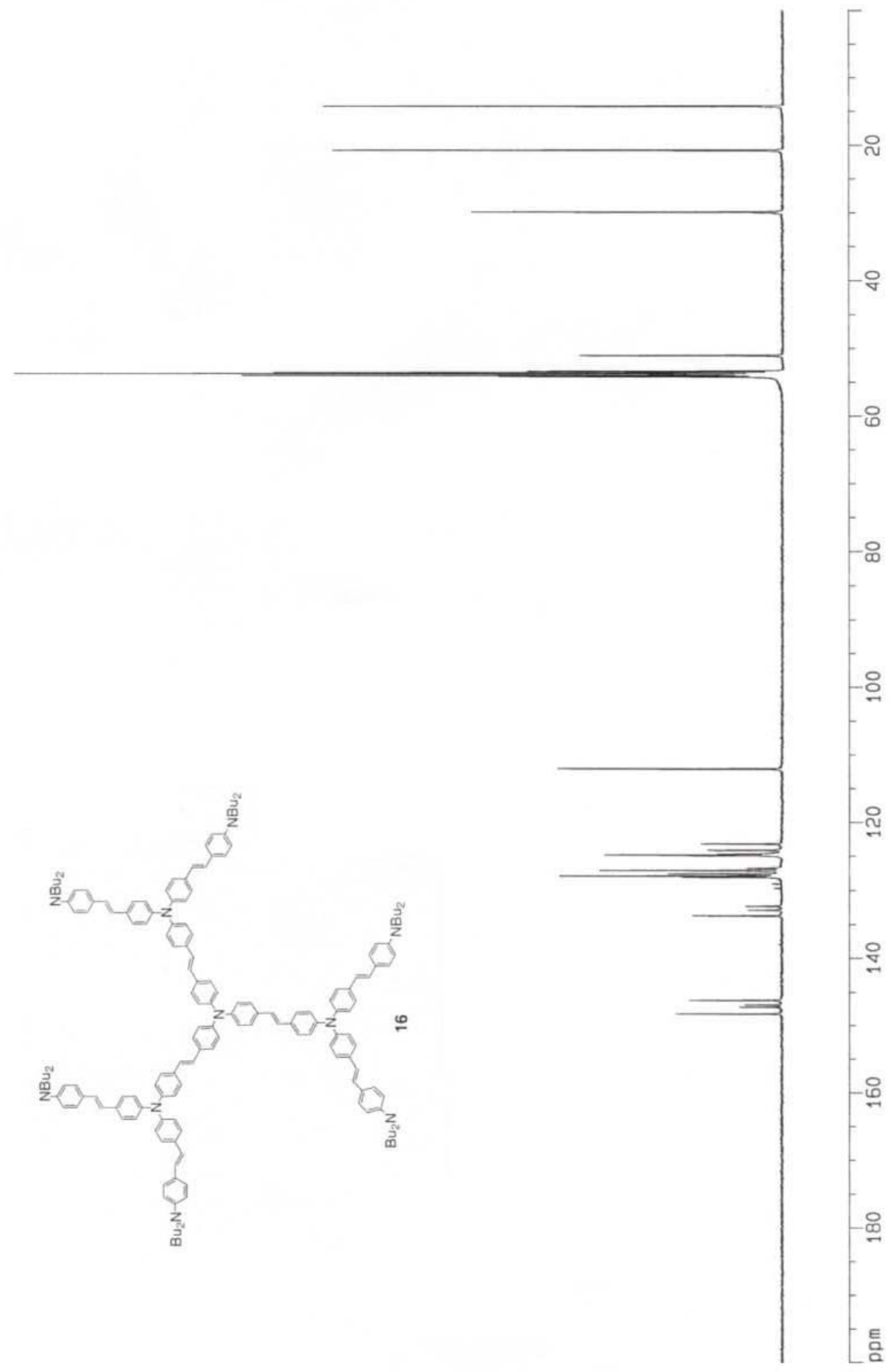

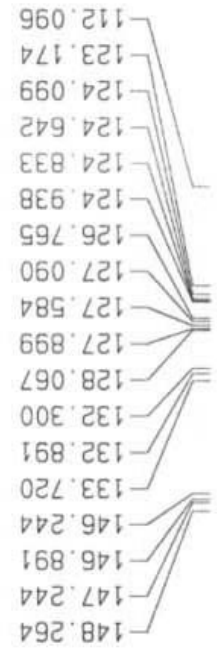

ㅇ

8

8

음

옹

운

웅

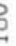

흠 


\section{One-photon and two-photon induced fluorescence emission of 16:}

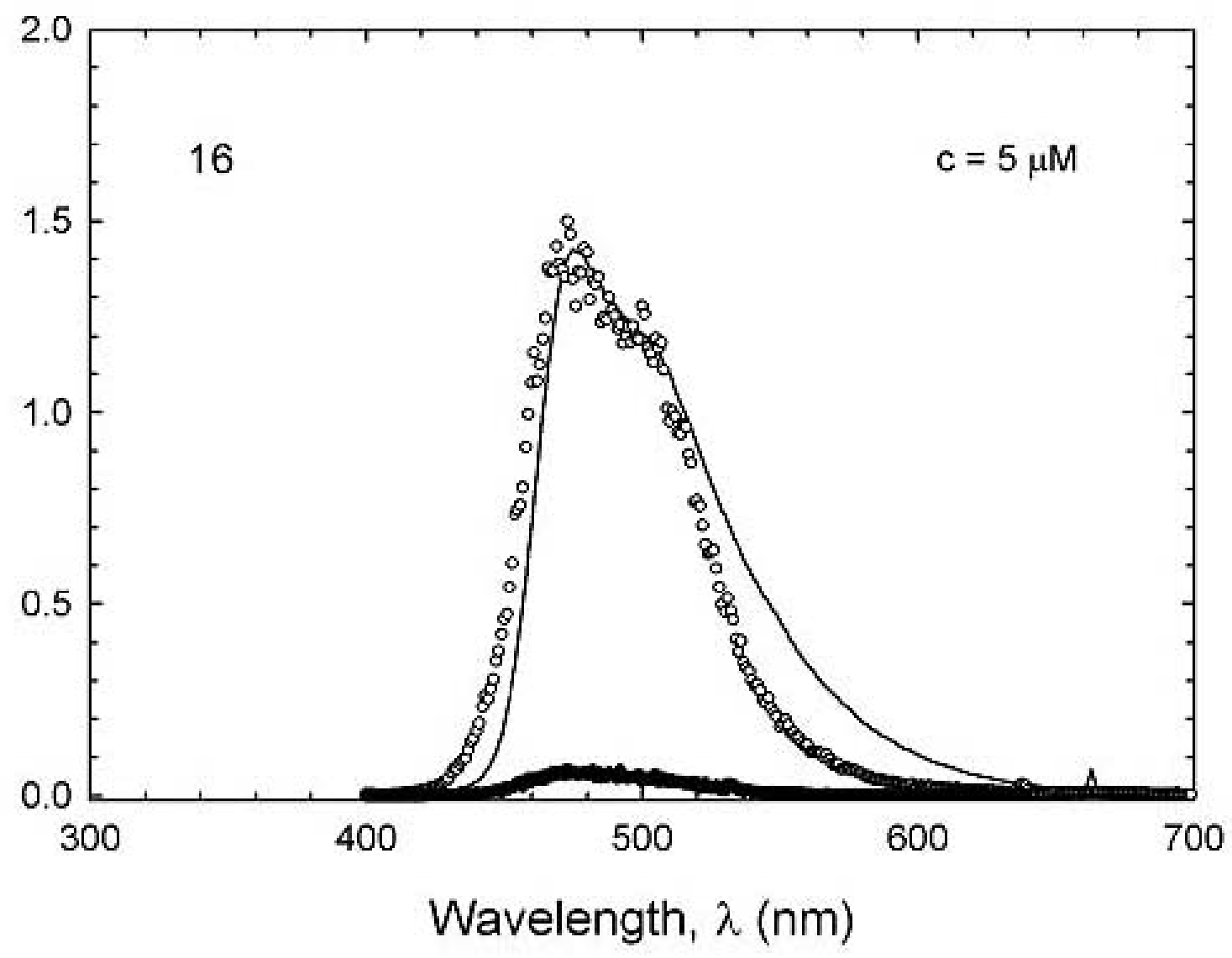

* one-photon fluorescence emission (solid line) and two-photon fluorescence emission (open circle: excited at $800 \mathrm{~nm}$; filled circle: excited at $660 \mathrm{~nm}$ ) of molecule $\mathbf{1 6 . .}$

\section{Reference:}

1. Horner, L.; Singer, R. J. Tetrahedron Lett. 1969, 10, 1545-1547.

2. Calo, V.; Ciminale, F.; Lopez, L.; Todesco, P. E. J. Chem. Soc. C. 1971, 21, $3652-3653$.

3. Lai, G.; Bu, X. R.; Santos, J.; Mintz, E. A. Synlett 1997, 1275-1276.

4. Tew, G. N.; Pralle, M. U.; Stupp, S. I. Angew. Chem. Int. Ed. 2000, 39, 517-521.

5. Rosenfeld, J. Anal. Lett. 1977, 10, 917-930. 